\title{
Factors Associated with Timely Test Seeking, Test Turnaround, and Public Reporting of COVID-19: a retrospective analysis in Ontario, Canada
}

\section{Authors:}

Eugene Joh, MPH

Sarah A. Buchan, $\mathrm{PhD}^{\mathrm{a}-\mathrm{c}}$

Nick Daneman, $\mathrm{MD}^{\mathrm{a}, \mathrm{d}-\mathrm{f}}$

Lauren A. Paul, MSc ${ }^{\mathrm{a}}$

Kevin A. Brown, $\mathrm{PhD}^{\mathrm{a}-\mathrm{c}}$

\author{
eugene.joh@oahpp.ca \\ sarah.buchan@oahpp.ca \\ nick.daneman@sunnybrook.ca \\ lauren.paul@oahpp.ca \\ kevin.brown@oahpp.ca
}

\section{Affiliations:}

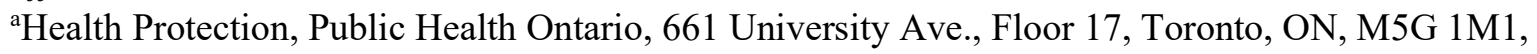
Canada

'bCES, 2075 Bayview Ave., Room G1 06, Toronto, ON, M4N 3M5, Canada

'Dalla Lana School of Public Health, University of Toronto, 155 College St., Room 500, Toronto, ON, M5T 3M7, Canada

${ }^{\mathrm{d} S u n n y b r o o k}$ Research Institute, Sunnybrook Health Sciences Centre, 2075 Bayview Ave., Toronto, ON, M4N 3M5, Canada

eDivision of Infectious Diseases, Sunnybrook Health Sciences Centre, 2075 Bayview Ave., Room B1 03, Toronto, ON, M4N 3M5, Canada

fInstitute of Health Policy, Management and Evaluation, University of Toronto, 155 College St., Suite 425, Toronto, ON, M5T 3M6, Canada

Corresponding Author:

Eugene Joh, MPH

Public Health Ontario

661 University Avenue, Floor 17

Toronto, Ontario, M5G 1M1

Tel: +1 (647) 260-7721

Email: eugene.joh@oahpp.ca 


\begin{abstract}
Background

Minimizing delays in disease identification and reporting improves the timeliness of surveillance data, and can reduce transmission of COVID-19. Our study investigates factors associated with timely testing and reporting of COVID-19 during the first pandemic wave in one province of Canada.
\end{abstract}

\title{
Methods
}

We identified all persons with confirmed SARS-CoV-2 infection residing in private households across the largest province of Canada, Ontario from the date of the first confirmed case in Ontario (January 25) to July 19, 2020. Our primary outcomes consisted of: (1) specimen collection within 1 day of symptom onset (test seeking), (2) test result reported to local public health within 1 day of specimen collection (test turnaround), and (3) entry of case data into the provincial database within 1 day of reporting test results (reporting). We examined 14 covariates including eight case characteristics, and six neighborhood characteristics. In addition to descriptive measures, logistic regression models were fitted. Unadjusted models included the covariate alone, while adjusted models included age, gender, month, and region.

\section{Findings}

Among 27,198 COVID-19 cases from January 252020 to July 19 2020, 28.7\% had timely test seeking, $40 \cdot 2 \%$ had timely test turnaround, and $75 \cdot 5 \%$ had timely reporting. Male gender had lower odds of timely test seeking (adjusted odds ratio [aOR] $0 \cdot 79$ [95\% CI: 0.74-0.85]) compared to females. Healthcare worker status (aOR $2 \cdot 77$ [95\% CI: 2.52-3.05] compared to non-healthcare workers), and age $\geq 80$ years (aOR $1 \cdot 59$ [95\% CI: $1 \cdot 33-1 \cdot 91]$ compared to $40-59$ year olds) were associated with timely test seeking. Specimen collection on Fridays and Saturdays (aOR 0.88 [95\% CI: 0.79-0.98], aOR 0.83 [95\% CI: 0.740.92 ] respectively, compared to Wednesdays) had lower odds of timely test turnaround. Urban areas (aOR 1.55 [95\% CI: 1.41-1.70] compared to rural areas) were associated with timely test turnaround. Urban areas (aOR 0.79 [95\% CI: 0.70-0.89] compared to rural areas) were less likely to have timely reporting.

\section{Interpretation}

Individual, neighborhood, and administrative factors are associated with timely testing and reporting of SARS-CoV-2 infections. These findings present considerations for developing targeted strategies to minimize delays and improve timely testing and reporting of SARS-CoV-2 infections.

\section{Funding}

This study was funded by Public Health Ontario. 


\section{Research in Context}

\section{Evidence before this study}

We searched PubMed and medRxiv up to November 302020 to identify studies examining the impact of delays in the disease reporting process on the public health response to COVID-19. We used the search terms ("2019-nCoV" OR "COVID-19" OR "SARS-CoV-2") AND ("delays" OR "timely" OR "reporting" OR "test" OR "turnaround"), and reviewed reference lists of any relevant articles in the original search. Numerous modeling studies have highlighted the importance of timely testing and reporting to effectively control the spread of COVID-19. Additional studies have also identified delays of only 1 day in testing were associated with increased risk of secondary transmission within households. However no study has described the multiple delays in the disease reporting process of COVID-19 and examined factors associated with timely disease reporting using a large population cohort.

\section{Added value of this study}

Our study described timely test seeking, test turnaround, and reporting for laboratory-confirmed COVID19 cases in Ontario, Canada and identified associated individual, neighbourhood, and administrative factors. To the best of our knowledge, this study is the first to describe detailed delays in the disease reporting process of COVID-19 and identified associated factors using a large population cohort.

\section{Implications of all the available evidence}

Numerous individual, neighborhood, and administrative characteristics are associated with timely testing and reporting of COVID-19. These identified factors may be used to develop strategies such as broadened test access, prioritization of vulnerable populations, and increased testing capacity to reduce delays in testing and reporting and improve the effectiveness of public health response to COVID- 19 . 


\section{Contributors}

EJ performed the analysis and drafted the manuscript. KB, SB, and ND conceptualized the study. KB, $\mathrm{SB}, \mathrm{ND}$, and $\mathrm{EJ}$ developed the methodology. KB, SB, and EJ verified the underlying data. LP contributed to the analysis. $\mathrm{KB}, \mathrm{SB}, \mathrm{ND}$, and $\mathrm{LP}$ reviewed the manuscript.

\section{Declaration of interests}

The authors have no conflicts of interest to declare.

\section{Data sharing}

Data sharing requests should be directed to Public Health Ontario. 


\section{Introduction}

Effective disease control via public health follow-up is contingent on rapid case identification to interrupt infection spread, and timely detection of secondary contacts. As case numbers increase, case and contact management may be delayed due to limited public health resources. Rapid case identification is critical to interrupting transmission, and the speed necessary to interrupt transmission varies across infections as a function of the time from symptom onset to the infectious period. ${ }^{1}$ Studies of COVID-19 viral kinetics and contact tracing have pointed to the prodromal phase of SARS-CoV-2 infection having the highest risk of transmission, with the peak of infectiousness thought to occur on and following the date of symptom onset, and culturable virus detected up to 9-10 days after symptom onset. ${ }^{2-5}$ This characteristic of COVID-19 points to the efficient spread of SARS-CoV-2 in the community and has made it challenging for public health to rapidly identify new cases before secondary transmission.

The process of disease reporting will inevitably have delays that can occur between symptom onset, specimen collection, laboratory testing, and reporting to public health. Minimizing both these individual and overall delays is critical in slowing the spread of COVID-19. Studies have shown longer delays are associated with increased risk of secondary household transmission and play a large role in whether COVID-19 outbreaks can be controlled. ${ }^{6,7}$

We sought to identify individual- and neighbourhood-level characteristics associated with timely testing and reporting of confirmed COVID-19 during the first COVID-19 wave in Ontario, Canada (defined as January to July 2020).

\section{Methods}

\section{Study population}

COVID-19 was designated as a mandatory reportable disease on January 22, 2020. From the provincial database we extracted information on persons with confirmed SARS-CoV-2 infection reported by laboratories to public health in Ontario, Canada from January 25, 2020 to July 19, 2020. ${ }^{8}$ As testing criteria, prioritization, and access differed across populations in Ontario, we excluded people belonging to congregate settings (e.g. nursing houses, retirement homes, shelters, agricultural settings, correctional facilities, and long-term care homes) based on criteria described elsewhere, ${ }^{7}$ thus restricting our cohort to residents of private households.

\section{Outcomes}

We generated three timeliness metrics based on the delays in the disease reporting process for each individual with COVID-19. These metrics were defined as: (1) the time between a case's symptom onset to when their specimen was collected for PCR testing (test seeking timeliness); (2) the time from when a case's specimen was collected to when a positive test result was reported to local public health (test turnaround timeliness); and (3) the time between when the test result was reported to when local public health entered the case's data in the provincial reportable disease systems (reporting timeliness). Our primary outcomes of interest were whether each metric was considered timely (delay of $\leq 1$ day). The thresholds were based on previous evidence of increased odds of secondary household transmission even with 1-day delay of test seeking, ${ }^{7}$ and suggested limits in testing delays of successful contact tracing. ${ }^{9,10}$ Persons with symptom onset occurring after a positive PCR test were considered to have timely test seeking. Individuals were excluded when the date of reporting occurred before specimen collection, and when date of data entry occurred before date of reporting, as we were unable to determine whether these 
were legitimate entries or due to data entry error. Individuals with missing date information on symptom onset or specimen collection were excluded for the timely test seeking metric, and individuals with missing date information on specimen collection were excluded from the timely test turnaround metric. Information on the date of when a positive test result was reported to public health was complete for all individuals.

\section{Individual-level characteristics}

Individual-level characteristics were extracted from the provincial reportable disease system: age, gender, and health region (Supplementary Material Table S1). Information on whether a case was part of a public health declared outbreak and whether the person's occupation was identified as a healthcare worker (doctor, nurse, dentist, dental hygienist, midwife, other medical technicians, personal support worker, respiratory therapist, and first responder) were also included. We extracted temporal covariates including month and day of week for each timeliness metric.

Individuals were classified as either an index household case or a secondary household case based on symptom onset date (or specimen collection date when symptom onset information was not available). Index cases were defined as the first case identified within an individual household. Secondary cases of COVID-19 within households were categorized based on the number of days from the index case (1-5, 6$10, \geq 11$ days). Index and secondary cases linked to an outbreak were identified and categorized in the same manner (1-5, 6-10, $\geq 11$ days from index case associated with an outbreak).

\section{Neighbourhood-level characteristics}

Information for neighbourhood-level characteristics were obtained from 2016 Canadian census data based on dissemination areas. ${ }^{11} \mathrm{We}$ linked individuals with COVID-19 to dissemination areas using postal codes; in rare instances when a resident postal code matched with multiple dissemination areas, the dissemination area with the largest population was selected. Neighborhood characteristics of interest included the percentage of non-White and non-Indigenous residents, recent immigration, wage below low-income cut-off (LICO), labour force status, attainment of high school education, and urban/rural status.

\section{Statistical Analysis}

We performed descriptive analyses to assess the characteristics of timely cases. Chi-squared tests, Student's t-tests, and Cochran-Mantel-Haenszel trend tests were used to test for differences in individualand neighbourhood-level characteristics among people with timely and non-timely metrics. Distributions of the test seeking, test turnaround, and reporting delays were generated. We used logistic regression models to determine characteristics associated with timeliness for each of the three metrics. For each outcome we fit unadjusted and adjusted models that accounted for age, gender, month, and health region. We reported odds ratios, unadjusted (OR) and unadjusted (aOR), with 95\% confidence intervals (95\% CI) for each characteristic. Odds ratios for neighbourhood-level covariates were reported per $10 \%$ increases. All analyses were conducted using $\mathrm{R}$ version $3 \cdot 6 \cdot 3$.

\section{Results}

As of July 19, 2020, there were 27,198 cases of COVID-19 in Ontario occurring outside of congregate settings (Figure 1). Of these cases 10,295 (37.9\%) had missing information on the date of symptom onset or date of testing, $6,525(24 \cdot 0 \%)$ were missing the date of testing, and no cases were missing the date test results were reported or the date of data entry. This resulted in 16,903 cases with complete test seeking 
delay information, 20,673 cases with test turnaround delay information and 27,198 cases with complete reporting information (Table 1).

Across the three metrics, $28 \cdot 7 \%$ of cases had timely test seeking, $40 \cdot 2 \%$ had timely test turnaround, and $75 \cdot 5 \%$ had timely reporting. Only $6 \cdot 6 \%$ of individuals with COVID- 19 were timely for all three metrics. The distribution of test seeking delays had greater dispersion (3 days, interquartile range [IQR]: 1-7) compared to test turnaround (2 days, IQR: 1-3) and reporting (1 day, IQR: 0-1) delays (Figure 2).

\section{Timely Test Seeking}

Males had significantly lower odds of timely testing compared to females (Table 2; aOR $=0.79$ [95\% CI: $0 \cdot 74-0 \cdot 85])$. Healthcare workers $(\mathrm{aOR}=2 \cdot 77[95 \% \mathrm{CI}: 2 \cdot 52-3 \cdot 05])$ and those aged $\geq 80$ years $(\mathrm{aOR}=$ $1 \cdot 59$ [95\% CI: 1.33-1.91]) had significantly higher odds of timely testing compared to cases with nonhealthcare occupation and cases aged 40-59 years, respectively. Secondary cases in both outbreak and household settings were more likely to have timely testing compared to index cases. There was a trend of increasing odds of timely testing by month of symptom onset among cases from March (aOR $=0 \cdot 29$ [95\% CI: 0·26-0·33]; reference $=$ May 2020) to July $(\mathrm{aOR}=2 \cdot 17$ [95\% CI: $1 \cdot 84-2 \cdot 56]$; reference $=$ May 2020). Symptom onset occurring on days adjacent to or on a weekend were associated with lower odds of timely test seeking. Urban areas had lower odds of timely test seeking compared to rural areas. Neighbourhood factors were not strongly associated with test seeking.

\section{Timely Test Turnaround}

Test turnaround for specimens collected on Fridays (aOR $=0.88$ [95\% CI: 0.79-0.98]) and Saturdays $(\mathrm{aOR}=0.83$ [95\% CI: 0.74-0.92]; reference $=$ Wednesday $)$ were less likely to be timely. Of the individual-level characteristics, healthcare workers (aOR $=1 \cdot 11$ [95\% CI: 1·02-1 20]) and those $\geq 80$ years old $(\mathrm{aOR}=1 \cdot 23$ [95\% CI: $1 \cdot 05-1 \cdot 43])$ had higher odds of timely test turnaround. Urban areas were more likely to have timely test turnaround compared to rural areas $(\mathrm{aOR}=1 \cdot 55$ [95\% CI: 1·41-1·70]).

\section{Timely Reporting}

Temporal trends of increasing timely reporting were observed, where March had significantly lower odds of timely reporting (Table 4; aOR $=0 \cdot 40$ [95\% CI: 0.36-0 44]) compared to May, whereas reporting in June $(\mathrm{aOR}=5 \cdot 25$ [95\% CI: 4·67-5·91]) and July (aOR $=8 \cdot 90$ [95\% CI: 7·00-11·31]) was much more likely to be timely. Urban areas had lower odds of timely test reporting compared to rural areas $(\mathrm{aOR}=$ $0 \cdot 79$ [95\% CI: 0.70-0.89]). Lower unadjusted odds of timely reporting were observed in neighbourhoods with a higher proportion of recent immigration $(\mathrm{OR}=0.46$ per $10 \%$ increase [95\% CI: $0.43-0 \cdot 49])$, visible minority $(\mathrm{OR}=0.91$ per $10 \%$ increase [95\% CI: $0.90-0.92])$, and LICO (OR $=0.62$ per $10 \%$ increase [95\% CI: $0 \cdot 60-0 \cdot 64]$ ). When adjusting age, gender, month of reporting and region, the associations weakened for recent immigration ( $\mathrm{aOR}=0 \cdot 85$ per $10 \%$ increase [95\% CI: $0 \cdot 79-0 \cdot 93]$ ), visible minority ( $\mathrm{aOR}=0.97$ per $10 \%$ increase [95\% CI: $0.95-0.98]$ ), and LICO (aOR $=0.99$ per $10 \%$ increase [95\% CI: 0.94-1.04]). Age and secondary case status were not strongly associated with timely reporting after adjustment.

\section{Discussion}

In this study we examined delays in testing and reporting from a cohort of 27,198 confirmed COVID-19 cases from non-congregate settings in Ontario, and identified factors associated with timely test seeking, test turnaround, and reporting. Factors associated with timely test seeking included female gender, healthcare workers, individuals aged $\geq 80$ years, and a previously identified index case within the same household; factors associated with timely test turnaround included age $\geq 80$ years, healthcare worker 
status, and residence in an urban area; and factors associated with timely reporting included month of reporting and residence in a rural areas. We noticed important weekend effects wherein there was decreased timeliness for test seeking, test turnaround, and reporting on Fridays and Saturdays.

Our analysis identified that test seeking was frequently delayed in our cohort. Various mathematical modelling studies have highlighted the importance of shortening the delay between symptom onset to diagnosis for effectively controlling COVID-19 outbreaks. ${ }^{10}$ Kretzschmar et al. found testing delays strongly influenced the ability of contact tracing strategies to reduce the effective reproduction number $(\mathrm{Re})$, such that testing delays of 3 days or longer preclude reduction of Re below 1, even with $100 \%$ tracing coverage. ${ }^{9}$ Hellewell et al. identified symptom onset to test delays play a major role in the probability of controlling an outbreak. ${ }^{6}$ Rong et al. conducted a study based on reported data from China in the first 3 months of the COVID-19 pandemic, and identified that the proportion of timely diagnosis was important in reducing the number of new infections and further transmission risk. ${ }^{12}$ Model results from Larremore et al. highlighted the increased importance of speed of testing, reporting, and contact tracing, over improved test sensitivities, to control COVID-19. ${ }^{13}$ Additional studies have identified the importance of faster testing from symptom onset to lower the risk of household transmission. ${ }^{7,14,15}$ While these studies suggest that increased timeliness of test seeking can lead to decreases in COVID-19 transmission, our study uses empirical evidence to identify factors associated with timeliness.

The trends of increasing timely test seeking during the study period were likely driven by changes in testing criteria and test access. ${ }^{16}$ Healthcare workers and vulnerable populations were recommended by the World Health Organization early in the pandemic for testing prioritization. ${ }^{17}$ In April, the provincial government of Ontario expanded testing to include these groups, specifically individuals working in healthcare settings. ${ }^{18}$ On May 29 testing in Ontario was opened to all individuals. ${ }^{19}$ The expanded testing criteria and increased test access via the rollout of assessment centre testing likely contributed to the increased timely test seeking observed in June and July. The gender differences for test seeking observed in this cohort may be explained by patterns of delayed healthcare seeking behaviour among men. ${ }^{20}$ Secondary cases of index cases linked to an outbreak or within a household were more likely to have timely test seeking than the index case. Our analysis describes the effect of testing criteria and factors associated with timely test seeking, which may be used to inform strategies such as expanded hours for testing including weekends, increased access to testing for working populations.

Timely test turnaround was more likely in healthcare workers compared to non-healthcare workers. A cross-sectional study of healthcare workers in US nursing homes identified $13.5 \%$ of facilities had test turnaround times within 1 day, and $16.4 \%$ in hot-spot counties. ${ }^{21} \mathrm{We}$ observed a higher proportion of timely test turnaround in our cohort, as this may be more reflective of different strategies and testing resources available across jurisdictions. Urban areas were more likely to have timely test turnaround compared to rural ones. This likely reflects the larger laboratory capacity in urban centers and challenges in the transport of samples in more rural areas. The reduction of timely test turnaround in June was likely driven by a reporting error a local hospital network that impacted roughly 500 cases. ${ }^{22}$ Our analysis also found timely test turnaround was less likely on Fridays and Saturdays. Weekend effects have been described for other facets of medical care, ${ }^{23}$ but this has not been previously described in medical laboratory testing. These weekend effects may be influenced by lower frequency in sample transportation that contributes to longer delays in test turnaround. This effect on timely testing may be determined by changes in laboratory capacity and staffing over the weekend.

Increasingly rapid reporting was observed from March to July and was likely driven by increasing local public health capacity in response to the growth of COVID-19 in Ontario and directives issued to local public health for required timely data entry of case information. Urban areas and regions that experienced 
large numbers COVID-19 cases in their jurisdictions, such as Toronto, were less likely to have timely reporting to the provincial database. This may also explain the lower odds of timely reporting observed for neighbourhoods with higher proportions of recent immigrants, visible minority, and low income as these neighbourhoods were typically found around the Toronto region. This highlights the impact of exponential growth and large outbreaks that may rapidly surge beyond public health capacity causing delays in timely disease reporting precisely when they are needed most.

Our study has limitations as this cohort was generated from cases arising from the first wave of COVID19 in Ontario, and these associations may not be generalizable to other populations/jurisdictions or subsequent time periods. There may be a degree of misclassification with index and secondary cases within households if members were not tested or if secondary cases had been infected outside of the home. Another limitation is that our outcomes of interest had incomplete data, specifically the test seeking and test turnaround delays. While the delay from symptom onset is likely a reasonable proxy of infection onset to test seeking for symptomatic patients, the delay in test seeking could not be measured relative to the start of true infectiousness among asymptomatic infections. Delays in timely test seeking were likely influenced by changes in test access, testing criteria, and laboratory capacity during our study period. Further, missing information on specimen collection led to incomplete test seeking and test turnaround outcomes. The large reporting error in June likely resulted in decreased timely test turnaround in our analysis. Changes in required data entry fields over our study period may have also impacted timely reporting. However the strengths of our study include a large population-based cohort; an examination of multiple delays in the disease reporting process; and a large number of individual, structural, and neighbourhood characteristics, including the identification of index and secondary cases within households. Our study provides empirical evidence on factors associated timely disease reporting, whereas many prior studies focused on modelling delays. To our knowledge this is the first study describing detailed delays in COVID-19 reporting in Canada.

This analysis described the delays in test seeking, test turnaround, and reporting across a cohort of community COVID-19 cases in Ontario. We identified numerous factors associated with timeliness which could be used to inform interventions. In particular, weekend effects were apparent for all delays, suggesting that expanded awareness, access, and capacity over the weekends may reduce delays. We also found improvements in timeliness for each stage of the disease reporting process over the course of the first pandemic wave. The findings of this study may be used to develop strategies to improve timely testing and reporting of SARS-CoV-2 infections. 


\section{References}

1 Marinović AB, Swaan C, van Steenbergen J, Kretzschmar M. Quantifying Reporting Timeliness to Improve Outbreak Control. Emerg Infect Dis 2015; 21(2):209-16.

2 He X, Lau EHY, Wu P, Deng X, Wang J, Hao X, et al. Temporal dynamics in viral shedding and transmissibility of COVID-19. Nature Medicine 2020; 26(5):672-5.

3 Cevik M, Tate M, Lloyd O, Maraolo AE, Schafers J, Ho A. SARS-CoV-2, SARS-CoV, and MERS-CoV viral load dynamics, duration of viral shedding, and infectiousness: a systematic review and meta-analysis. The Lancet Microbe 2020; 2(1):13-22.

4 Cevik M, Kuppalli K, Kindrachuk J, Peiris M. Virology, transmission, and pathogenesis of SARS-CoV-2. BMJ 2020; 371:m3862.

5 How long are people with COVID-19 infectious? Public Health Agency of Canada; 2020 Nov p. 436. Report No.: 11/12. Date accessed: December 3, 2020. Available from: https://www.canada.ca/content/dam/phac-aspc/documents/services/reports-publications/canadacommunicable-disease-report-ccdr/monthly-issue/2020-46/issue-11-12-nov-5-2020/ccdrv46i1112-eng.pdf

6 Hellewell J, Abbott S, Gimma A, Bosse NI, Jarvis CI, Russell TW, et al. Feasibility of controlling COVID-19 outbreaks by isolation of cases and contacts. The Lancet Global Health 2020; 8(4):e488-96.

7 Paul LA, Daneman N, Brown KA, Johnson J, van Ingen T, Joh E, et al. Characteristics associated with household transmission of SARS-CoV-2 in Ontario, Canada. medRxiv 2020: 2020.10.22.20217802

8 COVID-19 - Guidance for the Health Sector. Ontario Ministry of Health and Long-Term Care; 2020. Date accessed: November 17, 2020. Available from:

http://www.health.gov.on.ca/en/pro/programs/publichealth/coronavirus/2019_guidance.aspx

9 Kretzschmar ME, Rozhnova G, Bootsma MCJ, van Boven M, van de Wijgert JHHM, Bonten MJM. Impact of delays on effectiveness of contact tracing strategies for COVID-19: a modelling study. The Lancet Public Health 2020; 5(8):e452-9.

10 Ferretti L, Wymant C, Kendall M, Zhao L, Nurtay A, Abeler-Dörner L, et al. Quantifying SARSCoV-2 transmission suggests epidemic control with digital contact tracing. Science 2020; 368(6491):eabb6936.

11 Census data collection - Sampling and Weighting Technical Report, Census of Population, 2016. Statistics Canada; 2016. Date accessed: November 17, 2020. Date accessed: November 17, 2020. Available from: https://www12.statcan.gc.ca/census-recensement/2016/ref/98-306/ch1-eng.cfm\#a1

12 Rong XM, Yang L, Chu H di, Fan M. Effect of delay in diagnosis on transmission of COVID-19. Mathematical biosciences and engineering: MBE 2020; 17(3):2725-40.

13 Larremore DB, Wilder B, Lester E, Shehata S, Burke JM, Hay JA, et al. Test sensitivity is secondary to frequency and turnaround time for COVID-19 screening. Sci Adv 2020; eabd5393.

14 Wang Y, Tian H, Zhang L, Zhang M, Guo D, Wu W, et al. Reduction of secondary transmission of SARS-CoV-2 in households by face mask use, disinfection and social distancing: a cohort study in Beijing, China. BMJ Glob Health 2020; 5(5):e002794. 
15 Xin H, Jiang F, Xue A, Liang J, Zhang J, Yang F, et al. Risk factors associated with occurrence of COVID-19 among household persons exposed to patients with confirmed COVID-19 in Qingdao Municipal, China. Transboundary and Emerging Diseases 2020; 00:1-7.

16 COVID-19 in Ontario: A Summary of Wave 1 Transmission Patterns and Case Identification. Public Health Ontario; 2020. Date accessed: December 3, 2020. Available from: https://www.publichealthontario.ca/-/media/documents/ncov/epi/2020/08/covid-19-wave-1-transmissionpatterns-epi-summary.pdf?la=en

17 Critical preparedness, readiness and response actions for COVID-19. World Health Organization; 2020 Nov. Date accessed: November 17, 2020. Available from: https://apps.who.int/iris/bitstream/handle/10665/336373/WHO-COVID-19-Community_Actions-2020.5eng.pdf

18 Ontario Significantly Expanding COVID-19 Testing. Ontario Ministry of Health and Long-Term Care; 2020. Date accessed: November 17, 2020. Available from: https://news.ontario.ca/en/release/56644/ontario-significantly-expanding-covid-19-testing

19 Ontario Opens Up COVID-19 Testing Across the Province. Ontario Ministry of Health and LongTerm Care; 2020. Date accessed: November 18, 2020. Available from: https://news.ontario.ca/en/release/57053/ontario-opens-up-covid-19-testing-across-the-province

20 Thompson AE, Anisimowicz Y, Miedema B, Hogg W, Wodchis WP, Aubrey-Bassler K. The influence of gender and other patient characteristics on health care-seeking behaviour: a QUALICOPC study. BMC Family Practice 2016; 17(1):38.

21 McGarry BE, SteelFisher GK, Grabowski DC, Barnett ML. COVID-19 Test Result Turnaround Time for Residents and Staff in US Nursing Homes. JAMA Internal Medicine 2020; Available from: https://doi.org/10.1001/jamainternmed.2020.7330

22 Rocca R. Hundreds of positive coronavirus tests weren't reported to Ontario public health units. 2020; Date accessed: November 18, 2020. Available from: https://globalnews.ca/news/7017710/positivecoronavirus-tests-ontario-not-reported/

23 Ruiz M, Bottle A, Aylin PP. The Global Comparators project: international comparison of 30-day in-hospital mortality by day of the week. BMJ Qual Saf 2015; 24(8):492. 
medRxiv preprint doi: https://doi.org/10.1101/2021.02.22.21252219; this version posted February 23, 2021. The copyright holder for this preprint (which was not certified by peer review) is the author/funder, who has granted medRxiv a license to display the preprint in perpetuity.

\section{It is made available under a CC-BY-NC-ND 4.0 International license .}

Figures and Tables

Figure 1: Cohort Flowchart

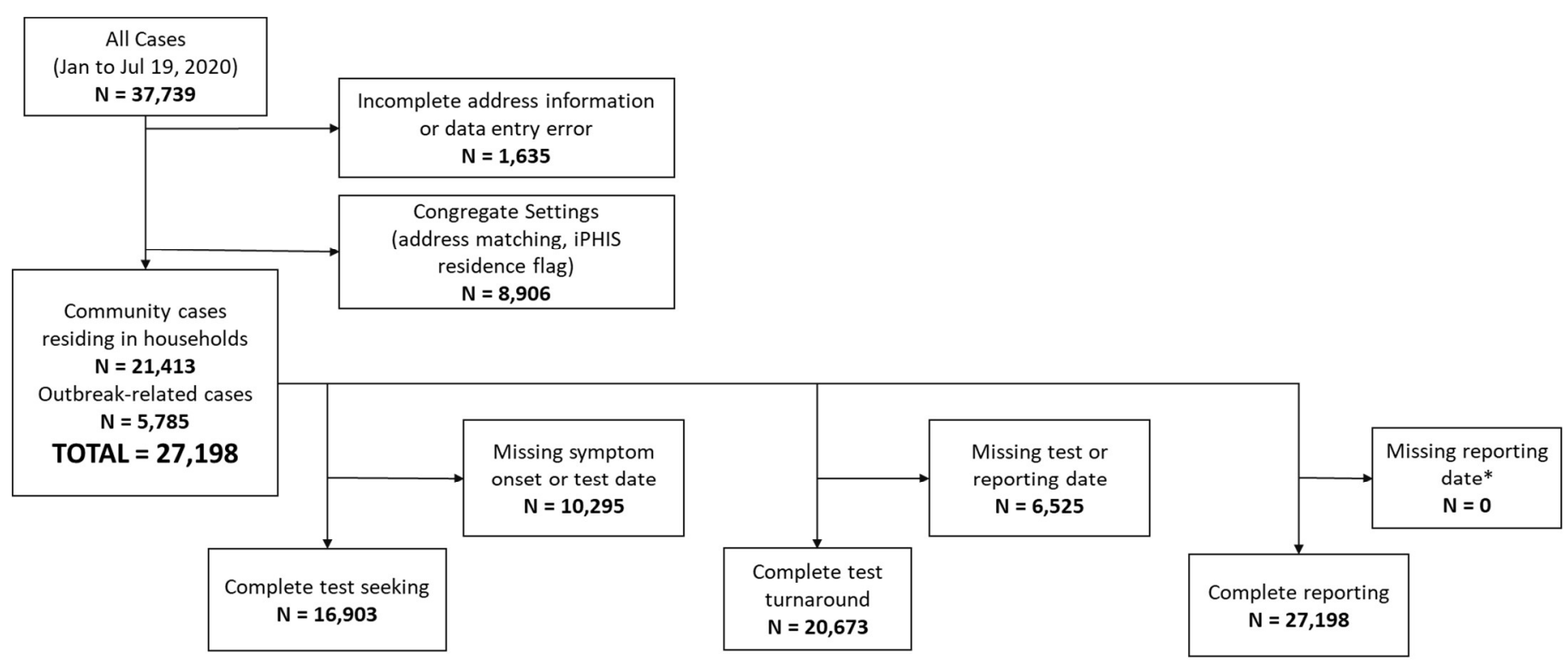

*Data entry date is complete for all cases 
medRxiv preprint doi: https://doi.org/10.1101/2021.02.22.21252219; this version posted February 23, 2021. The copyright holder for this preprint (which was not certified by peer review) is the author/funder, who has granted medRxiv a license to display the preprint in perpetuity. It is made available under a CC-BY-NC-ND 4.0 International license.

Table 1: Timeliness of test seeking, test turnaround, and reporting Complete Cases Timely $(\mathrm{N})$ $(\mathrm{N}, \%)$ Duration of Delay (days)

\begin{tabular}{llll}
\hline Test seeking & 16,903 & $4,859(28 \cdot 7 \%)$ & $3(1,7)$ \\
\hline Test turnaround & 20,673 & $8,316(40 \cdot 2 \%)$ & $2(1,3)$ \\
\hline Reporting & 27,198 & $20,535(75 \cdot 5 \%)$ & $1(0,1)$
\end{tabular}


medRxiv preprint doi: https://doi.org/10.1101/2021.02.22.21252219; this version posted February 23, 2021. The copyright holder for this preprint (which was not certified by peer review) is the author/funder, who has granted medRxiv a license to display the preprint in perpetuity.

It is made available under a CC-BY-NC-ND 4.0 International license .

Table 2: Factors associated with timely test seeking

\begin{tabular}{|c|c|c|c|c|c|}
\hline & $\begin{array}{l}\text { Total }(\mathbf{N}=\mathbf{1 6 , 9 0 3 )} \\
\text { (Median }[\mathrm{IQR}] \text { or } \\
\mathrm{N}[\%])\end{array}$ & $\begin{array}{l}\text { Timely }(\mathbf{N}=\mathbf{4 , 8 5 9}) \\
\text { (Median }[\mathrm{IQR}] \text { or } \\
\mathrm{N}[\%])\end{array}$ & p value & $\begin{array}{l}\text { Odds Ratio } \\
(95 \% \mathrm{CI})\end{array}$ & $\begin{array}{l}\text { Adjusted Odds } \\
\text { Ratio }(95 \% \text { CI }) \dagger\end{array}$ \\
\hline Month of Symptom Onset & & & $<0.001$ & & \\
\hline March and Earlier & 3,818 & $483(12 \cdot 7 \%)$ & & $0 \cdot 30(0 \cdot 27-0 \cdot 33)$ & $0.29(0.26-0.33)$ \\
\hline April & 5,704 & $1,675(29 \cdot 4 \%)$ & & $0 \cdot 85(0.78-0.93)$ & $0.84(0.77-0.91)$ \\
\hline May & 4,576 & $1,499(32 \cdot 8 \%)$ & & reference & reference \\
\hline June & 2,138 & $860(40 \cdot 2 \%)$ & & $1 \cdot 38(1 \cdot 24-1 \cdot 54)$ & $1 \cdot 40(1 \cdot 26-1 \cdot 56)$ \\
\hline July & 667 & $342(51 \cdot 3 \%)$ & & $2 \cdot 16(1 \cdot 83-2 \cdot 54)$ & $2 \cdot 17(1 \cdot 84-2 \cdot 56)$ \\
\hline $\begin{array}{l}\text { Weekday of Symptom } \\
\text { Onset }\end{array}$ & & & $0 \cdot 010$ & & \\
\hline Sunday & 2,207 & $618(28 \cdot 0 \%)$ & & $0 \cdot 91(0 \cdot 80-1 \cdot 03)$ & $0.94(0.83-1.07)$ \\
\hline Monday & 2,712 & $787(29 \cdot 0 \%)$ & & $0 \cdot 96(0 \cdot 85-1 \cdot 08)$ & $0.98(0 \cdot 87-1 \cdot 11)$ \\
\hline Tuesday & 2,427 & $742(30 \cdot 6 \%)$ & & $1 \cdot 03(0 \cdot 91-1 \cdot 17)$ & $1 \cdot 07(0 \cdot 95-1 \cdot 22)$ \\
\hline Wednesday & 2,405 & $720(29 \cdot 9 \%)$ & & reference & reference \\
\hline Thursday & 2,280 & $731(32 \cdot 1 \%)$ & & $1 \cdot 10(0 \cdot 98-1 \cdot 25)$ & $1 \cdot 10(0 \cdot 97-1 \cdot 25)$ \\
\hline Friday & 2,580 & $690(26 \cdot 7 \%)$ & & $0 \cdot 85(0 \cdot 76-0.97)$ & $0.85(0.75-0.97)$ \\
\hline Saturday & 2,292 & $571(24 \cdot 9 \%)$ & & $0 \cdot 78(0 \cdot 68-0 \cdot 88)$ & $0.78(0.69-0.89)$ \\
\hline Age (years) & & & $<0 \cdot 001$ & & \\
\hline $0-19$ & 960 & $338(35 \cdot 2 \%)$ & & $1 \cdot 37(1 \cdot 19-1 \cdot 58)$ & $1 \cdot 10(0 \cdot 95-1 \cdot 28)$ \\
\hline $20-39$ & 5,971 & $1,739(29 \cdot 1 \%)$ & & $1 \cdot 04(0 \cdot 96-1 \cdot 12)$ & $0.96(0.89-1.04)$ \\
\hline $40-59$ & 6,356 & $1,804(28 \cdot 4 \%)$ & & reference & reference \\
\hline $60-79$ & 3,008 & $760(25 \cdot 3 \%)$ & & $0.85(0.77-0.94)$ & $0.96(0.87-1.07)$ \\
\hline$\geq 80$ & 608 & $218(35 \cdot 9 \%)$ & & $1 \cdot 41(1 \cdot 18-1 \cdot 68)$ & $1.59(1.33-1.91)$ \\
\hline Gender & & & $<0 \cdot 001$ & & \\
\hline Female & 8,976 & $2,761(30 \cdot 8 \%)$ & & reference & reference \\
\hline Male & 7,888 & $2,082(26 \cdot 4 \%)$ & & $0 \cdot 81(0 \cdot 75-0 \cdot 86)$ & $0.79(0.74-0.85)$ \\
\hline Healthcare Worker & & & $<0 \cdot 001$ & & \\
\hline No & 10,294 & $2,542(24 \cdot 7 \%)$ & & reference & reference \\
\hline Yes & 3,813 & $1,540(40 \cdot 4 \%)$ & & $2 \cdot 07(1 \cdot 91-2 \cdot 24)$ & $2 \cdot 77(2.52-3.05)$ \\
\hline $\begin{array}{l}\text { Outbreak Secondary } \\
\text { Transmission }\end{array}$ & & & $<0 \cdot 001$ & & \\
\hline Index case & 13,904 & $3,483(25 \cdot 1 \%)$ & & reference & reference \\
\hline
\end{tabular}


medRxiv preprint doi: https://doi.org/10.1101/2021.02.22.21252219; this version posted February 23, 2021. The copyright holder for this preprint (which was not certified by peer review) is the author/funder, who has granted medRxiv a license to display the preprint in perpetuity.

It is made available under a CC-BY-NC-ND 4.0 International license.

\begin{tabular}{|c|c|c|c|c|c|}
\hline & $\begin{array}{l}\text { Total }(\mathbf{N}=\mathbf{1 6 , 9 0 3 )} \\
\text { (Median }[\mathrm{IQR}] \text { or } \\
\mathrm{N}[\%])\end{array}$ & $\begin{array}{l}\text { Timely }(\mathbf{N}=\mathbf{4 , 8 5 9}) \\
\text { (Median }[\mathrm{IQR}] \text { or } \\
\mathrm{N}[\%])\end{array}$ & p value & $\begin{array}{l}\text { Odds Ratio } \\
(95 \% \mathrm{CI})\end{array}$ & $\begin{array}{l}\text { Adjusted Odds } \\
\text { Ratio }(95 \% \mathrm{CI}) \dagger\end{array}$ \\
\hline 1-5 days & 588 & $239(40 \cdot 6 \%)$ & & $2 \cdot 05(1 \cdot 73-2 \cdot 43)$ & $2 \cdot 22(1 \cdot 86-2 \cdot 64)$ \\
\hline 6-10 days & 592 & $265(44 \cdot 8 \%)$ & & $2 \cdot 42(2 \cdot 05-2 \cdot 86)$ & $2 \cdot 63(2 \cdot 21-3 \cdot 12)$ \\
\hline$\geq 11$ days & 1,819 & $872(47 \cdot 9 \%)$ & & $2 \cdot 76(2 \cdot 49-3 \cdot 04)$ & $2 \cdot 68(2 \cdot 41-2 \cdot 98)$ \\
\hline $\begin{array}{l}\text { Household Secondary } \\
\text { Transmission }\end{array}$ & & & $<0.001$ & & \\
\hline Index case & 14,124 & $3,882(27 \cdot 5 \%)$ & & reference & reference \\
\hline 1-5 days & 1,599 & $518(32 \cdot 4 \%)$ & & $1 \cdot 26(1 \cdot 13-1 \cdot 41)$ & $1 \cdot 12(1 \cdot 00-1 \cdot 26)$ \\
\hline 6-10 days & 690 & $245(35 \cdot 5 \%)$ & & $1 \cdot 45(1 \cdot 24-1 \cdot 71)$ & $1 \cdot 34(1 \cdot 14-1 \cdot 58)$ \\
\hline$\geq 11$ days & 490 & $214(43 \cdot 7 \%)$ & & $2 \cdot 05(1 \cdot 70-2 \cdot 45)$ & $1.73(1.43-2.09)$ \\
\hline Visible Minority & $34 \cdot 9(16 \cdot 1,65 \cdot 6)$ & $36 \cdot 2(17 \cdot 5,65 \cdot 6)$ & $0 \cdot 010$ & $1 \cdot 02(1 \cdot 00-1 \cdot 03)$ & $0.96(0.94-0.97)$ \\
\hline Recent Immigration & $3 \cdot 9(1 \cdot 6,7 \cdot 5)$ & $4 \cdot 2(1 \cdot 8,7 \cdot 5)$ & $0 \cdot 001$ & $1 \cdot 13(1 \cdot 05-1 \cdot 22)$ & $0.88(0.80-0.98)$ \\
\hline Low-income Cut-off & $11 \cdot 5(5 \cdot 8,17 \cdot 9)$ & $12 \cdot 1(5 \cdot 9,18 \cdot 3)$ & $0 \cdot 128$ & $1 \cdot 03(0 \cdot 99-1 \cdot 07)$ & $0.90(0.86-0.95)$ \\
\hline Labour Force & $63 \cdot 7(59 \cdot 3,68 \cdot 7)$ & $64 \cdot 0(59 \cdot 5,69 \cdot 0)$ & $0 \cdot 010$ & $1 \cdot 07(1 \cdot 02-1 \cdot 12)$ & $1 \cdot 18(1 \cdot 09-1 \cdot 22)$ \\
\hline No High School Education & $18 \cdot 1(13 \cdot 6,23 \cdot 6)$ & $18 \cdot 4(13 \cdot 6,23 \cdot 9)$ & $0 \cdot 298$ & $1 \cdot 02(0.98-1 \cdot 07)$ & $0.92(0.88-0.96)$ \\
\hline Urban/Rural & & & $0 \cdot 334$ & & \\
\hline Rural & 2931 & $821(28 \cdot 0 \%)$ & & reference & reference \\
\hline Urban & 13,893 & $4,015(28 \cdot 9 \%)$ & & $1 \cdot 04(0 \cdot 96-1 \cdot 14)$ & $0.84(0.75-0.93)$ \\
\hline Region & & & $<0.001$ & & \\
\hline Central East & 3,801 & $1,088(28 \cdot 6 \%)$ & & $0 \cdot 96(0 \cdot 85-1.09)$ & $0.84(0.73-0.96)$ \\
\hline Central West & 2,390 & $623(26 \cdot 1 \%)$ & & $0 \cdot 85(0.74-0.97)$ & $0.76(0.66-0.88)$ \\
\hline East & 1,665 & $489(29 \cdot 4 \%)$ & & reference & reference \\
\hline North & 244 & $56(23 \cdot 0 \%)$ & & $0.72(0.52-0.98)$ & $0 \cdot 84(0 \cdot 61-1 \cdot 17)$ \\
\hline South West & 1,660 & $413(24 \cdot 9 \%)$ & & $0 \cdot 80(0.68-0.93)$ & $0.73(0.62-0.86)$ \\
\hline Toronto & 7,140 & $2,189(30 \cdot 7 \%)$ & & $1 \cdot 06(0 \cdot 95-1 \cdot 20)$ & $0.84(0.74-0.95)$ \\
\hline
\end{tabular}

$\uparrow$ Adjusted models included age, gender, month of symptom onset, and region. 
medRxiv preprint doi: https://doi.org/10.1101/2021.02.22.21252219; this version posted February 23, 2021. The copyright holder for this preprint (which was not certified by peer review) is the author/funder, who has granted medRxiv a license to display the preprint in perpetuity.

It is made available under a CC-BY-NC-ND 4.0 International license .

Table 3: Factors associated with timely test turnaround

\begin{tabular}{|c|c|c|c|c|c|}
\hline & $\begin{array}{l}\text { Total }(\mathbf{N}=\mathbf{2 0 , 6 7 3}) \\
\text { (Median }[\mathrm{IQR}] \text { or } \\
\mathrm{N}[\%])\end{array}$ & $\begin{array}{l}\text { Timely }(\mathbf{N}=\mathbf{8 , 3 1 6}) \\
\text { (Median }[\mathrm{IQR}] \text { or } \\
\mathrm{N}[\%] \text { ) }\end{array}$ & p value & $\begin{array}{l}\text { Odds Ratio } \\
(95 \% \mathrm{CI})\end{array}$ & $\begin{array}{l}\text { Adjusted Odds } \\
\text { Ratio }(95 \% \text { CI }) \dagger\end{array}$ \\
\hline Month of Testing & & & $<0.001$ & & \\
\hline March and Earlier & 2,736 & $940(34 \cdot 4 \%)$ & & $0.72(0.66-0.80)$ & $0.68(0.61-0.75)$ \\
\hline April & 7,161 & $3,325(46 \cdot 4 \%)$ & & $1 \cdot 20(1 \cdot 12-1 \cdot 29)$ & $1 \cdot 17(1 \cdot 09-1 \cdot 25)$ \\
\hline May & 6,007 & $2,519(41 \cdot 9 \%)$ & & reference & reference \\
\hline June & 3,547 & $1,053(29 \cdot 7 \%)$ & & $0.58(0.54-0.64)$ & $0.60(0.55-0.65)$ \\
\hline July & 1,222 & $479(39 \cdot 2 \%)$ & & $0.89(0.79-1.01)$ & $0.90(0.79-1.02)$ \\
\hline Weekday of Testing & & & $<0.001$ & & \\
\hline Sunday & 2,097 & $974(46 \cdot 4 \%)$ & & $1 \cdot 32(1 \cdot 19-1 \cdot 48)$ & $1 \cdot 33(1 \cdot 19-1 \cdot 50)$ \\
\hline Monday & 3,410 & $1,486(43 \cdot 6 \%)$ & & $1 \cdot 18(1 \cdot 07-1 \cdot 30)$ & $1 \cdot 24(1 \cdot 12-1 \cdot 37)$ \\
\hline Tuesday & 3,337 & $1,343(40 \cdot 2 \%)$ & & $1 \cdot 03(0 \cdot 93-1 \cdot 14)$ & $1.08(0.98-1.20)$ \\
\hline Wednesday & 3,177 & $1,257(39 \cdot 6 \%)$ & & reference & reference \\
\hline Thursday & 3,120 & $1,279(41 \cdot 0 \%)$ & & $1.06(0.96-1 \cdot 17)$ & $1.06(0.96-1 \cdot 18)$ \\
\hline Friday & 3,013 & $1,096(36 \cdot 4 \%)$ & & $0.87(0.79-0.97)$ & $0.88(0.79-0.98)$ \\
\hline Saturday & 2,519 & $881(35 \cdot 0 \%)$ & & $0.82(0.74-0.92)$ & $0.83(0.74-0.92)$ \\
\hline Age (years) & & & $0 \cdot 005$ & & \\
\hline $0-19$ & 1,288 & $526(40 \cdot 8 \%)$ & & $1 \cdot 01(0 \cdot 90-1 \cdot 14)$ & $1.07(0.95-1 \cdot 21)$ \\
\hline $20-39$ & 7,311 & $2,846(38 \cdot 9 \%)$ & & $0.93(0 \cdot 88-1 \cdot 00)$ & $0.96(0.89-1.02)$ \\
\hline $40-59$ & 7,678 & $3,113(40 \cdot 5 \%)$ & & reference & reference \\
\hline $60-79$ & 3,643 & $1,489(40 \cdot 9 \%)$ & & $1 \cdot 01(0 \cdot 94-1 \cdot 10)$ & $1 \cdot 03(0.95-1 \cdot 12)$ \\
\hline$\geq 80$ & 753 & $342(45 \cdot 4 \%)$ & & $1 \cdot 22(1 \cdot 05-1 \cdot 42)$ & $1.23(1.05-1 \cdot 43)$ \\
\hline Gender & & & $0 \cdot 054$ & & \\
\hline Female & 11,008 & $4,494(40 \cdot 8 \%)$ & & reference & reference \\
\hline Male & 9,599 & $3,792(39 \cdot 5 \%)$ & & $0.95(0.90-1.00)$ & $0.99(0.94-1.05)$ \\
\hline Healthcare Worker & & & $<0.001$ & & \\
\hline No & 12,382 & $4,931(39 \cdot 8 \%)$ & & reference & reference \\
\hline Yes & 4,665 & $2,089(44 \cdot 8 \%)$ & & $1 \cdot 23(1 \cdot 14-1 \cdot 31)$ & $1 \cdot 11(1 \cdot 02-1 \cdot 20)$ \\
\hline $\begin{array}{l}\text { Outbreak Secondary } \\
\text { Transmission }\end{array}$ & & & $<0.001$ & & \\
\hline Index case & 16,642 & $6,559(39 \cdot 4 \%)$ & & reference & reference \\
\hline 1-5 days & 725 & $303(41 \cdot 8 \%)$ & & $1 \cdot 10(0 \cdot 95-1 \cdot 28)$ & $0.98(0 \cdot 84-1 \cdot 14)$ \\
\hline
\end{tabular}


medRxiv preprint doi: https://doi.org/10.1101/2021.02.22.21252219; this version posted February 23, 2021. The copyright holder for this preprint (which was not certified by peer review) is the author/funder, who has granted medRxiv a license to display the preprint in perpetuity.

It is made available under a CC-BY-NC-ND 4.0 International license .

\begin{tabular}{|c|c|c|c|c|c|}
\hline & $\begin{array}{l}\text { Total }(\mathbf{N}=\mathbf{2 0 , 6 7 3 )} \\
\text { (Median }[\mathrm{IQR}] \text { or } \\
\mathrm{N}[\%])\end{array}$ & $\begin{array}{l}\text { Timely }(\mathbf{N}=\mathbf{8 , 3 1 6}) \\
\text { (Median }[\mathrm{IQR}] \text { or } \\
\mathrm{N}[\%])\end{array}$ & p value & $\begin{array}{l}\text { Odds Ratio } \\
(95 \% \mathrm{CI})\end{array}$ & $\begin{array}{l}\text { Adjusted Odds } \\
\text { Ratio }(95 \% \text { CI }) \dagger\end{array}$ \\
\hline 6-10 days & 749 & $337(45 \cdot 0 \%)$ & & $1 \cdot 26(1 \cdot 09-1 \cdot 46)$ & $1 \cdot 10(0 \cdot 94-1 \cdot 28)$ \\
\hline$\geq 11$ days & 2,557 & $1,117(43 \cdot 7 \%)$ & & $1 \cdot 19(1 \cdot 10-1 \cdot 30)$ & $0.99(0.91-1.08)$ \\
\hline $\begin{array}{l}\text { Household Secondary } \\
\text { Transmission }\end{array}$ & & & $0 \cdot 525$ & & \\
\hline Index case & 17,038 & $6,856(40 \cdot 2 \%)$ & & reference & reference \\
\hline 1-5 days & 1,932 & $798(41 \cdot 3 \%)$ & & $1 \cdot 05(0 \cdot 95-1 \cdot 15)$ & $1.07(0 \cdot 97-1 \cdot 18)$ \\
\hline 6-10 days & 915 & $355(38 \cdot 8 \%)$ & & $0 \cdot 94(0 \cdot 82-1 \cdot 08)$ & $0.94(0.82-1.09)$ \\
\hline$\geq 11$ days & 788 & $307(39 \cdot 0 \%)$ & & $0 \cdot 95(0 \cdot 82-1 \cdot 10)$ & $1 \cdot 02(0 \cdot 88-1 \cdot 18)$ \\
\hline Visible Minority & $37 \cdot 3(17 \cdot 8,67 \cdot 2)$ & $36 \cdot 5(18 \cdot 9,65 \cdot 6)$ & $0 \cdot 192$ & $0 \cdot 99(0 \cdot 98-1 \cdot 00)$ & $1 \cdot 00(0 \cdot 98-1 \cdot 01)$ \\
\hline Recent Immigration & $4 \cdot 2(1 \cdot 9,7 \cdot 7)$ & $4 \cdot 2(2 \cdot 0,7 \cdot 7)$ & $0 \cdot 696$ & $1 \cdot 01(0 \cdot 95-1 \cdot 08)$ & $1 \cdot 03(0.95-1 \cdot 11)$ \\
\hline Low-income Cut-off & $12 \cdot 6(6 \cdot 0,18 \cdot 6)$ & $13 \cdot 2(6 \cdot 3,19 \cdot 5)$ & $<0 \cdot 001$ & $1 \cdot 10(1 \cdot 07-1 \cdot 14)$ & $1 \cdot 14(1 \cdot 10-1 \cdot 19)$ \\
\hline Labour Force & $63 \cdot 5(59 \cdot 2,68 \cdot 5)$ & $63 \cdot 7(59 \cdot 3,69 \cdot 0)$ & $<0.001$ & $1 \cdot 11(1 \cdot 07-1 \cdot 16)$ & $1 \cdot 06(1 \cdot 01-1 \cdot 11)$ \\
\hline No High School Education & $18 \cdot 5(13 \cdot 6,24 \cdot 3)$ & $17 \cdot 9(12 \cdot 9,23 \cdot 1)$ & $<0.001$ & $0.82(0.79-0.85)$ & $0.88(0.84-0.91)$ \\
\hline Urban/Rural & & & $<0.001$ & & \\
\hline Rural & 3,330 & $1,064(32 \cdot 0 \%)$ & & reference & reference \\
\hline Urban & 17,236 & $7,202(41 \cdot 8 \%)$ & & $1 \cdot 53(1 \cdot 41-1 \cdot 65)$ & $1.55(1.41-1 \cdot 70)$ \\
\hline Region & & & $<0.001$ & & \\
\hline Central East & 4,296 & $1,556(36 \cdot 2 \%)$ & & $0 \cdot 33(0 \cdot 29-0 \cdot 37)$ & $0 \cdot 33(0 \cdot 30-0 \cdot 37)$ \\
\hline Central West & 2,648 & $1,125(42 \cdot 5 \%)$ & & $0 \cdot 43(0 \cdot 38-0 \cdot 48)$ & $0.43(0.38-0.49)$ \\
\hline East & 1,888 & $1,197(63 \cdot 4 \%)$ & & reference & reference \\
\hline North & 271 & $71(26 \cdot 2 \%)$ & & $0 \cdot 20(0 \cdot 15-0 \cdot 27)$ & $0 \cdot 20(0 \cdot 15-0 \cdot 27)$ \\
\hline South West & 1,974 & $560(28 \cdot 4 \%)$ & & $0 \cdot 23(0 \cdot 20-0 \cdot 26)$ & $0 \cdot 23(0 \cdot 20-0 \cdot 27)$ \\
\hline Toronto & 9,587 & $3,805(39 \cdot 7 \%)$ & & $0 \cdot 38(0 \cdot 34-0 \cdot 42)$ & $0 \cdot 38(0 \cdot 35-0 \cdot 43)$ \\
\hline
\end{tabular}

$\uparrow$ Adjusted models included age, gender, month of testing, and region. 
Table 4: Factors associated with timely reporting

\begin{tabular}{|c|c|c|c|c|c|}
\hline & $\begin{array}{l}\text { Total }(\mathbf{N}=\mathbf{2 7 , 1 9 8 )} \\
\text { (Median }[\mathrm{IQR}] \text { or } \\
\mathrm{N}[\%])\end{array}$ & $\begin{array}{l}\text { Timely }(\mathbf{N}=\mathbf{2 0 , 5 3 5 )} \\
\text { (Median }[\mathrm{IQR}] \text { or } \\
\mathrm{N}[\%])\end{array}$ & p value & $\begin{array}{l}\text { Odds Ratio } \\
(95 \% \mathrm{CI})\end{array}$ & $\begin{array}{l}\text { Adjusted Odds } \\
\text { Ratio }(95 \% \mathrm{CI}) \dagger\end{array}$ \\
\hline Month of Reporting & & & $<0 \cdot 001$ & & \\
\hline March and earlier & 2,591 & $1,662(64 \cdot 1 \%)$ & & $0.67(0.61-0.74)$ & $0.40(0.36-0.44)$ \\
\hline April & 9,015 & $6,073(67 \cdot 4 \%)$ & & $0 \cdot 78(0 \cdot 73-0 \cdot 83)$ & $0 \cdot 55(0 \cdot 51-0 \cdot 59)$ \\
\hline May & 8,495 & $6,174(72 \cdot 7 \%)$ & & reference & reference \\
\hline June & 5,167 & $4,772(92 \cdot 4 \%)$ & & $4 \cdot 54(4 \cdot 06-5 \cdot 09)$ & $5 \cdot 25(4 \cdot 67-5 \cdot 91)$ \\
\hline July & 1,930 & $1,854(96 \cdot 1 \%)$ & & $9 \cdot 17(7 \cdot 26-11 \cdot 59)$ & $8 \cdot 90(7 \cdot 00-11 \cdot 31)$ \\
\hline Weekday of Reporting & & & $0 \cdot 660$ & & \\
\hline Sunday & 3,443 & $2,658(77 \cdot 2 \%)$ & & $0 \cdot 98(0 \cdot 88-1.09)$ & $0.97(0 \cdot 85-1 \cdot 09)$ \\
\hline Monday & 3,949 & $2,891(73 \cdot 2 \%)$ & & $0 \cdot 79(0 \cdot 71-0 \cdot 87)$ & $0.77(0.69-0.87)$ \\
\hline Tuesday & 3,798 & $2,801(73 \cdot 7 \%)$ & & $0 \cdot 81(0 \cdot 73-0 \cdot 90)$ & $0 \cdot 79(0 \cdot 70-0 \cdot 89)$ \\
\hline Wednesday & 3,985 & $3,092(77 \cdot 6 \%)$ & & reference & reference \\
\hline Thursday & 3,995 & $3,094(77 \cdot 4 \%)$ & & $0 \cdot 99(0 \cdot 89-1 \cdot 10)$ & $1 \cdot 14(1 \cdot 01-1 \cdot 29)$ \\
\hline Friday & 4,330 & $3,171(73 \cdot 2 \%)$ & & $0 \cdot 79(0 \cdot 71-0 \cdot 87)$ & $0.83(0.74-0.93)$ \\
\hline Saturday & 3,698 & $2,828(76 \cdot 5 \%)$ & & $0 \cdot 94(0 \cdot 84-1 \cdot 04)$ & $0 \cdot 92(0 \cdot 82-1 \cdot 04)$ \\
\hline Age (years) & & & $<0 \cdot 001$ & & \\
\hline $0-19$ & 1,804 & $1,479(82 \cdot 0 \%)$ & & $1 \cdot 66(1 \cdot 46-1 \cdot 88)$ & $0 \cdot 98(0 \cdot 85-1 \cdot 13)$ \\
\hline $20-39$ & 9,748 & $7,527(77 \cdot 2 \%)$ & & $1 \cdot 23(1 \cdot 16-1 \cdot 32)$ & $1 \cdot 08(1 \cdot 00-1 \cdot 16)$ \\
\hline $40-59$ & 9,992 & $7,325(73 \cdot 3 \%)$ & & reference & reference \\
\hline $60-79$ & 4,749 & $3,561(75 \cdot 0 \%)$ & & $1 \cdot 09(1 \cdot 01-1 \cdot 18)$ & $1 \cdot 11(1 \cdot 02-1 \cdot 21)$ \\
\hline$\geq 80$ & 905 & $643(71 \cdot 0 \%)$ & & $0 \cdot 89(0 \cdot 77-1 \cdot 04)$ & $1 \cdot 04(0 \cdot 88-1 \cdot 23)$ \\
\hline Gender & & & $0 \cdot 233$ & & \\
\hline Female & 14,305 & $10,768(75 \cdot 3 \%)$ & & reference & reference \\
\hline Male & 12,816 & $9,727(75 \cdot 9 \%)$ & & $1 \cdot 03(0 \cdot 98-1 \cdot 09)$ & $1 \cdot 01(0 \cdot 95-1 \cdot 08)$ \\
\hline Healthcare Worker & & & $<0 \cdot 001$ & & \\
\hline No & 16,861 & $12,813(76 \cdot 0 \%)$ & & reference & reference \\
\hline Yes & 5,906 & $4,333(73 \cdot 4 \%)$ & & $0 \cdot 87(0 \cdot 81-0 \cdot 93)$ & $1 \cdot 03(0 \cdot 95-1 \cdot 12)$ \\
\hline $\begin{array}{l}\text { Outbreak Secondary } \\
\text { Transmission }\end{array}$ & & & $<0.001$ & & \\
\hline Index case & 22,371 & $17,091(76 \cdot 4 \%)$ & & reference & reference \\
\hline $1-5$ days & 841 & $598(71 \cdot 1 \%)$ & & $0.76(0.65-0.89)$ & $0 \cdot 95(0 \cdot 80-1 \cdot 13)$ \\
\hline
\end{tabular}




\begin{tabular}{|c|c|c|c|c|c|}
\hline & $\begin{array}{l}\text { Total }(\mathbf{N}=\mathbf{2 7 , 1 9 8 )} \\
\text { (Median }[\mathrm{IQR}] \text { or } \\
\mathrm{N}[\%])\end{array}$ & $\begin{array}{l}\text { Timely }(\mathbf{N}=\mathbf{2 0 , 5 3 5 )} \\
\text { (Median }[\mathrm{IQR}] \text { or } \\
\mathrm{N}[\%])\end{array}$ & p value & $\begin{array}{l}\text { Odds Ratio } \\
(95 \% \mathrm{CI})\end{array}$ & $\begin{array}{l}\text { Adjusted Odds } \\
\text { Ratio }(95 \% \text { CI })\end{array}$ \\
\hline 6-10 days & 884 & $603(68 \cdot 2 \%)$ & & $0.66(0.57-0.77)$ & $0 \cdot 85(0 \cdot 72-1 \cdot 01)$ \\
\hline$\geq 11$ days & 3,102 & $2,243(72 \cdot 3 \%)$ & & $0 \cdot 81(0 \cdot 74-0 \cdot 88)$ & $0 \cdot 94(0 \cdot 85-1 \cdot 03)$ \\
\hline $\begin{array}{l}\text { Household Secondary } \\
\text { Transmission }\end{array}$ & & & $<0.001$ & & \\
\hline Index case & 21,995 & $16,477(74 \cdot 9 \%)$ & & reference & reference \\
\hline 1-5 days & 2,848 & $2,218(77 \cdot 9 \%)$ & & $1 \cdot 18(1 \cdot 07-1 \cdot 29)$ & $0 \cdot 95(0 \cdot 85-1 \cdot 06)$ \\
\hline 6-10 days & 1,171 & $898(76 \cdot 7 \%)$ & & $1 \cdot 10(0 \cdot 96-1 \cdot 27)$ & $0 \cdot 98(0 \cdot 84-1 \cdot 15)$ \\
\hline$\geq 11$ days & 1,184 & $942(79 \cdot 6 \%)$ & & $1 \cdot 30(1 \cdot 13-1 \cdot 51)$ & $0 \cdot 93(0 \cdot 79-1 \cdot 10)$ \\
\hline Visible Minority & $44 \cdot 5(21 \cdot 0,73 \cdot 3)$ & $42 \cdot 1(18 \cdot 4,73 \cdot 0)$ & $<0.001$ & $0.91(0.90-0.92)$ & $0.97(0.95-0.98)$ \\
\hline Recent Immigration & $5 \cdot 0(2 \cdot 3,8 \cdot 0)$ & $4 \cdot 4(2 \cdot 0,7 \cdot 6)$ & $<0.001$ & $0 \cdot 46(0 \cdot 43-0 \cdot 49)$ & $0.85(0.79-0.93)$ \\
\hline Low-income Cut-off & $10 \cdot 7(6 \cdot 4,17 \cdot 2)$ & $9 \cdot 4(5 \cdot 9,16 \cdot 4)$ & $<0.001$ & $0 \cdot 62(0 \cdot 60-0 \cdot 64)$ & $0.99(0.94-1 \cdot 04)$ \\
\hline Labour Force & $64 \cdot 5(60 \cdot 1,69 \cdot 1)$ & $65 \cdot 1(60 \cdot 5,69 \cdot 3)$ & $<0.001$ & $1 \cdot 32(1 \cdot 26-1 \cdot 38)$ & $1 \cdot 09(1 \cdot 04-1 \cdot 15)$ \\
\hline No High School Education & $18 \cdot 5(14 \cdot 2,23 \cdot 3)$ & $18 \cdot 3(14 \cdot 2,23 \cdot 0)$ & $<0.001$ & $0 \cdot 87(0 \cdot 84-0 \cdot 90)$ & $0.91(0.87-0.95)$ \\
\hline Urban/Rural & & & $<0 \cdot 001$ & & \\
\hline Rural & 3,599 & $3,154(87 \cdot 6 \%)$ & & reference & reference \\
\hline Urban & 23,096 & $16,977(73 \cdot 5 \%)$ & & $0 \cdot 39(0.35-0.43)$ & $0.79(0.70-0.89)$ \\
\hline Region & & & $<0.001$ & & \\
\hline Central East & 9,832 & $8,409(85 \cdot 5 \%)$ & & $0.66(0 \cdot 57-0 \cdot 78)$ & $0 \cdot 50(0 \cdot 42-0 \cdot 58)$ \\
\hline Central West & 3,370 & $2,810(83 \cdot 4 \%)$ & & $0.56(0.48-0.67)$ & $0 \cdot 48(0 \cdot 41-0.58)$ \\
\hline East & 1,998 & $1,796(89 \cdot 9 \%)$ & & reference & reference \\
\hline North & 275 & $214(77 \cdot 8 \%)$ & & $0.39(0.29-0.54)$ & $0 \cdot 42(0 \cdot 30-0 \cdot 58)$ \\
\hline South West & 2,084 & $1,921(92 \cdot 2 \%)$ & & $1 \cdot 33(1 \cdot 07-1 \cdot 65)$ & $1 \cdot 09(0 \cdot 87-1 \cdot 36)$ \\
\hline Toronto & 9,629 & $5,376(55 \cdot 8 \%)$ & & $0 \cdot 14(0 \cdot 12-0 \cdot 17)$ & $0 \cdot 08(0 \cdot 07-0 \cdot 10)$ \\
\hline
\end{tabular}

$\uparrow$ Adjusted models included age, gender, month of reporting, and region. 
medRxiv preprint doi: https://doi.org/10.1101/2021.02.22.21252219; this version posted February 23, 2021. The copyright holder for this preprint (which was not certified by peer review) is the author/funder, who has granted medRxiv a license to display the preprint in perpetuity.

It is made available under a CC-BY-NC-ND 4.0 International license.

Figure 2: Distribution of Timeliness Metrics. Distribution of test seeking (symptom onset to specimen collection), test turnaround (specimen collection to test result), and reporting (test result to reporting) delays. Solid regions represent COVID-19 cases that were timely ( $\leq 1$ day), while transparent regions represent cases that were delayed ( $>1$ day). The dotted line denotes zero-day delay or events occurring on the same day.

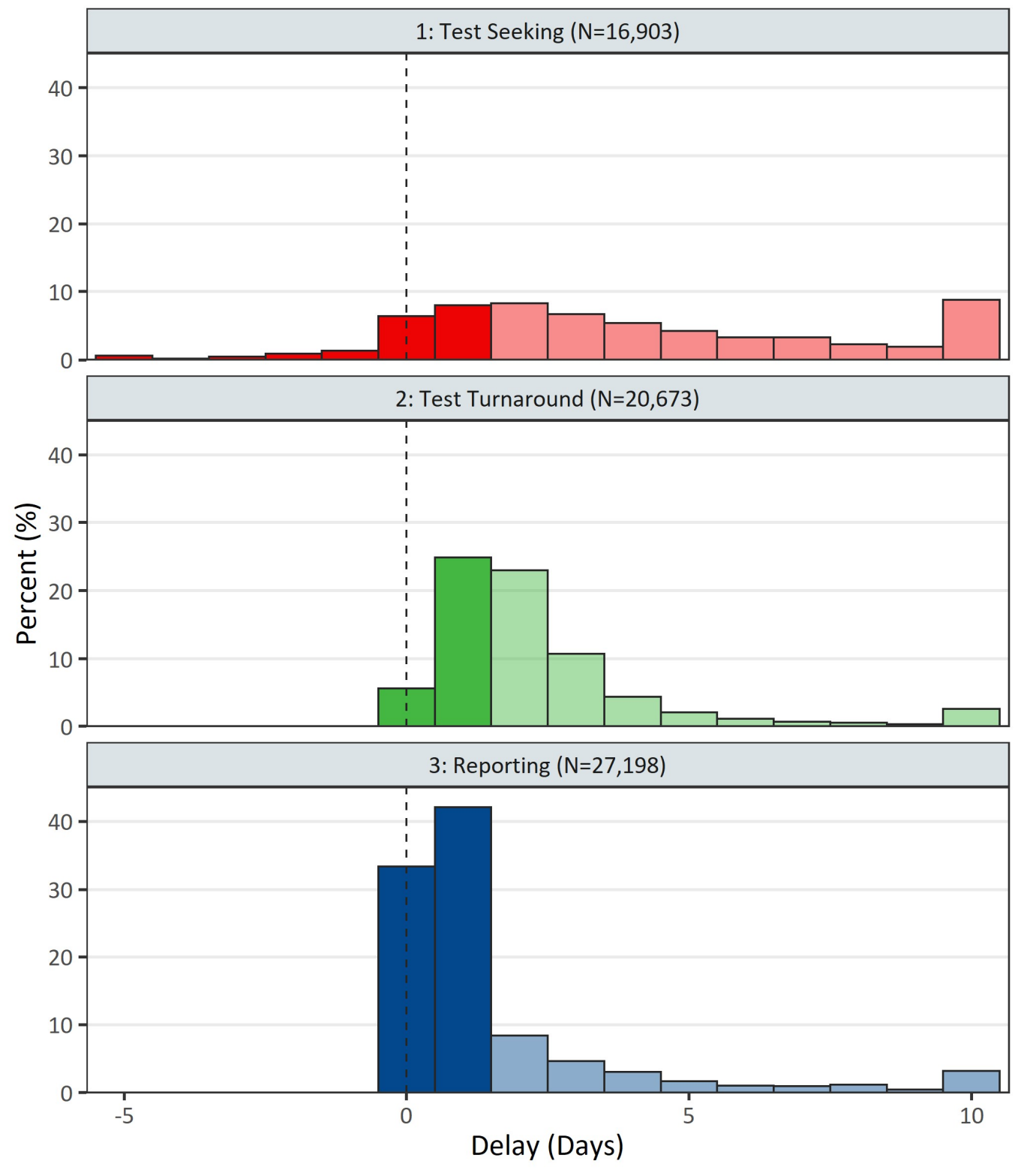

